\title{
USE OF SINGLE-ENZYME AMPLIFIED FRAGMENT LENGTH POLYMORPHISM FOR TYPING CLOSTRIDIUM PERFRINGENS ISOLATED FROM DIARRHEIC PIGLETS
}

\author{
Luciane Tieko Shinya ${ }^{1}$; Maria Regina Baccaro² ${ }^{2}$ Andrea Micke Moreno ${ }^{1 *}$ \\ ${ }^{1}$ Departamento de Medicina Veterinária Preventiva e Saúde Animal, Faculdade de Medicina Veterinária e Zootecnia, \\ Universidade de São Paulo, São Paulo, SP, Brasil; ${ }^{2}$ Departamento de Patologia, Faculdade de Medicina Veterinária e Zootecnia, \\ Universidade de São Paulo, SP, Brasil
}

Submitted: July 29, 2005; Returned to authors for corrections: March 13, 2006; Approved: June 14, 2006

\begin{abstract}
Clostridium perfringens is an important pathogen in human and veterinary medicine. In swine, the agent is responsible for necrotic enteritis and enterotoxemia characterized by diarrhea, weight loss, delayed development and, in some cases, death. In the present study amplified fragment length polymorphism analyses (AFLP) was used to characterize 54 C. perfringens strains isolated from swine presenting diarrhea. Analysis of the results showed 29 distinct profiles with discriminatory index equal to 0.97 . Partial correlation between the origin of the isolates and groups was drawn, and correlation was possible in only $18.5 \%$ of the samples. Characterization of the strains in biotypes (A, B, C, D and E), production of beta- 2 toxin and enterotoxin were performed by means of the polymerase chain reaction (PCR). Biotypes A, C and D were observed among the strains analyzed. All samples were positive for presence of the gene encoding beta-2 toxin and negative for the gene encoding enterotoxin. AFLP have shown to be a simple, fast, low cost method with high discriminative power and good reproducibility, presenting a great potential in epidemiological studies involving $C$. perfringens strains of animal origin.
\end{abstract}

Key words: AFLP, diarrhea, piglets, Clostridium perfringens

\section{INTRODUCTION}

Clostridium perfringens is an important cause of enteric disease both in humans and domestic animals (14). The bacteria produce several toxins that play key roles in the pathogenesis of disease. Toxins are classified into five biotypes, designated A - E, based on the differential production of alpha $(\alpha)$, beta $(\beta)$, epsilon ( $(\varepsilon)$, and iota (I) toxins. $C$. perfringens type $C$ is generally considered the primary cause of necrotic enteritis in piglets from 0 to 2 weeks of age, while type A has been linked to enteric disease in suckling and feeding pigs with mild necrotic enterocolitis (7). A novel toxin produced by $C$. perfringens, named beta 2- ( $\beta 2-)$ toxin, has recently been identified and its encoding gene has been characterized. This toxin is cytotoxic for intestinal cells and lethal for mice (2). Preliminary studies suggested that $\beta 2$-toxin-producing strains are associated with necrotic enteritis in piglets and enterocolitis and typhlocolitis in horses $(2,4)$.

Both phenotypic and genotypic methods have been investigated in the epidemiological typing of $C$. perfringens from human sources, including the use of bacteriocin, bacteriophage, plasmid analysis, pulsed-field gel electrophoresis (PFGE) and single-enzyme amplified fragment length polymorphism (10).

Literature does not present any study involving the typing of samples isolated from enteritis in swine. Genetic analysis of isolates from swine may lead to a better understanding of the transmission of the agent in swine production, as well as aid the choice of the best vaccination program and the recognition of the contamination potential of this agent in carcasses in the slaughterhouse.

*Corresponding Author. Mailing address: Departamento de Patologia, Faculdade de Medicina Veterinária e Zootecnia, USP. Av. Prof. Dr. Orlando Marques de Paiva, n.87, Cidade Universitária. 05508-000, São Paulo, SP, Brasil. Fax: (+5511) 3091-7928. E-mail: morenoam@uol.com.br 
The objectives of this trial were to characterize $C$. perfringens strains isolated from swine for to the presence of alpha, beta, epsilon, iota, enterotoxin and $\beta-2$ toxins genes using PCR, as well as to analyze $C$. perfringens genetic variability of isolates through the single-enzyme amplified fragment length polymorphism (SE-AFLP) method.

\section{MATERIALS AND METHODS}

\section{Bacterial strains}

A total of 54 isolates of organisms previously identified as C. perfringens were used in this study (11). The strains were obtained from eleven animals presenting neonatal diarrhea in eight herds located in three States of Brazil: Santa Catarina, Paraná, and Minas Gerais. The reference strains of $C$. perfringens biotype A (ATCC 3624), biotype B (ATCC 3626), biotype C (ATCC 3628) and biotype D (ATCC 3629) kindly offered by Instituto Biológico of São Paulo were used as positive controls in toxin genes detection through PCR.

\section{DNA extraction}

C. perfringens reference strains and cultures were grown in brain hearth infusion broth (BHI, Difco/BBL- Texas), at $37^{\circ} \mathrm{C}$ for 18-24 h. For PCR and SE-AFLP, total cellular DNA was purified with the guanidium thiocyanate method as previously described (13).

\section{Toxin gene detection}

PCR assays were performed using the DNA Thermal Cycler PT 200 (MJ Research) and using specific primers to toxin genes as previously described (11). The reactions were performed in $25 \mu \mathrm{L}$ volumes containing $5.0 \mu \mathrm{L}$ of DNA template, $1.5 \mathrm{mM} \mathrm{MgCl}_{2}, 200 \mathrm{mM}$ of each dNTP, 250 pmol of each oligonucleotide primer and 1.25 U of Taq DNA polymerase in 1 X PCR buffer (Invitrogen, São Paulo). The mixture was subjected to an initial denaturing step of $94^{\circ} \mathrm{C}$ for $4 \mathrm{~min}$, followed by 35 cycles of $94^{\circ} \mathrm{C}$ for $1 \mathrm{~min}, 55^{\circ} \mathrm{C}$ for $1 \mathrm{~min}$, and $72^{\circ} \mathrm{C}$ for $1 \mathrm{~min}$.

\section{Restriction endonuclease digestion, ligation of adapters and PCR}

An aliquot containing $10 \mu \mathrm{g}$ of DNA was digested overnight (16 h) at $37^{\circ} \mathrm{C}$ with $24 \mathrm{U}$ of Hind III (Invitrogen, São Paulo) in the buffer provided with the enzyme and ultra pure water in a final volume of $20 \mu \mathrm{L}$. A $5 \mu \mathrm{L}$ aliquot containing the digested DNA was used in a ligation reaction containing $0.2 \mu \mathrm{g}$ of each adapter oligonucleotide (ADH1-5' ACGGTATGCGACAG 3' and ADH23' GAGTGCCATACGCTGTCTCGA 5'), 1 U of T4 DNA ligase (Invitrogen, São Paulo), ligase buffer, and water, in a final volume of $20 \mu \mathrm{L}$ incubated at room temperature for $3 \mathrm{~h}$. Ligated DNA was heated to $80^{\circ} \mathrm{C}$ for $10 \mathrm{~min}$, diluted $1 / 5$ in sterile distilled water, and $5 \mu \mathrm{L}$ were used for each reaction.

\section{PCR reaction}

PCR reactions were performed in $50 \mu \mathrm{L}$ final volumes and contained $5 \mu \mathrm{L}$ of ligated DNA, $2.5 \mathrm{mM} \mathrm{MgCl}_{2}, 300 \mathrm{ng}$ of primer HIG-5'GGTATGCGACAGAGCTTG 3' and 1.25 U of Taq DNA polymerase in $1 \mathrm{X}$ PCR buffer. The mixture was submitted to an initial denaturing step of $94^{\circ} \mathrm{C}$ for $4 \mathrm{~min}$, followed by 35 cycles of $94^{\circ} \mathrm{C}$ for $1 \mathrm{~min}, 60^{\circ} \mathrm{C}$ for $1 \mathrm{~min}$, and $72^{\circ} \mathrm{C}$ for $2.5 \mathrm{~min}$.

The amplified products were analyzed on a $2.0 \%$ agarose gel, stained with ethidium bromide $(0.5 \mathrm{mg} / \mu \mathrm{L})$, observed by UV transilumination, and registered by an image capturing system (ImageMaster VDS, Amersham Pharmacia Biotech). A 100 bp DNA ladder (Invitrogen, São Paulo) was included twice on each electrophoresis gel. Banding patterns were assessed visually, considering only strong and moderately stained fragments. Analyses of the SE-AFLP banding patterns were performed blindly and under code with respect to the biotype and epidemiological data.

\section{Discriminatory index}

The discriminatory power of the SE-AFLP typing method was calculated as described by Hunter and Gaston (5).

Discriminatory index:

$$
\mathbf{D I}=1-\frac{1}{N(\mathrm{~N}-1)_{j=1}} \sum \mathrm{n}_{\mathrm{j}}^{\mathrm{s}}\left(\mathrm{n}_{\mathrm{j}}-1\right)
$$

Where $N$ is the number of strains, $s$ is number of types, and $n_{j}$ is number of strains with type $j$.

\section{Statistical analysis}

Analysis of the banding patterns was done with the Software NTSYS (Numerical Taxonomy and Multivariate Analysis System) with the Jaccard coefficient. In general, strains were considered clonal if they showed $100 \%$ similarity. Band patterns were clustered to deduce a dendrogram by the unweighted pair group method with arithmetic averages.

\section{RESULTS}

Analysis of genes $c p a, c p b, c p b-2$, cpe, ia and etx using PCR showed the presence of three different biotypes. From the 54 samples tested for the presence of genes encoding toxins, $39(72.2 \%)$ were classified as type A, $7(13 \%)$ as type C and $8(14.8 \%)$ as type D. Samples isolated from the same animal were classified as different biotypes, and isolates from each animal were either C. perfringens type A and type C, or type A and type $\mathrm{D}$. All samples presented gene $c p a$, which confirmed their identification as $C$. perfringens, and gene $c p b-2$ encoding toxin $\beta-2$. Besides, all isolates were negative for genes et $x$ and $i a$, and type $\mathrm{E}$, type $\mathrm{B}$ or enterotoxin-producing strains were not found. 
Analysis of the samples tested by SE-AFLP showed the presence of 29 profiles characterized as AP1-AP29. Each profile produced from 4 to $12 \mathrm{DNA}$ fragments (bands) of approximately 380-2,072 pb (Fig. 1). Profiles found were different in relation to the presence or absence of at least one band, and all of them presented one band of approximately 1,050 and $1,450 \mathrm{pb}$. In order to test the reproducibility, three separate preparations of $10 \mathrm{C}$. perfringens isolates were submitted to SE-AFLP, and no band variation was observed. However, some variations in the intensities of bands were observed with different PCR assays.

It was observed that all samples isolated from the same animal presented different profiles as accessed by SE-AFLP, and that, in some cases, samples that came from different herds showed similar profiles.

Samples belonging to the same biotype, when tested by SEAFLP presented different patterns. Sample of $C$. perfringens type A presented 21 different profiles in AFLP; type C ones presented four different profiles and type $\mathrm{D}$ ones, six different profiles.

AFLP produced a dendogram (Fig. 2) in which two groups may be observed with a similarity rate equal to $27.5 \%$. Group I presented $81.5 \%(44 / 54)$ of the samples analyzed. This group was made up of two subgroups that present at least $42.5 \%$ of similarity (Ia and Ib). Subgroup Ia presented 23 samples that belonged to two different biotypes, type $\mathrm{A}$ and type $\mathrm{C}$, with similarity rate of approximately $60 \%$. The other subgroup, called $\mathrm{Ib}$, presented 21 samples from three different biotypes, type A, $\mathrm{C}$ and $\mathrm{D}$, with similarity rate of $60 \%$.

Group II presented $18.5 \%$ (10/54) of the isolates, with at least $83 \%$ of similarity. This group showed samples from only one genotype that came from the same herd.

\section{DISCUSSION}

Detection of genes encoding $C$. perfringens toxins by PCR has been used by several authors, for it makes unnecessary to use laboratory animals and does not depend on the in vitro sporulation of the organism, what potentially reduces falsenegative results (9). Frequency of genes $c p a, c p b$ and $c p b-2$ in the study was similar to the results obtained by Garmory et al. and Klaasen et al. (1,7). These authors describe the predominance of isolates in types $\mathrm{A}$ and $\mathrm{C}$ positive for gene $c p b-2$. No reports were found in the literature on the occurrence of type D samples related to swine diarrhea, as observed in the present study.

Typing is an important epidemiological tool for the recognition of outbreaks, detection of cross-contamination and determination of the source of infection, recognition of virulent strains and monitoring of vaccination programs (12). Different vaccines to be used in the prevention of the infection by $C$. perfringens are available in the Brazilian market nowadays. However, the occurrence of diarrhea caused by this agent has been observed even in herds that have vaccination programs. This fact may be related to the great genetic variability of this agent, as it was observed in the present study.

The analysis of the 54 samples of $C$. perfringens using SEAFLP showed 29 different subtypes, as it was previously observed (10) in human samples, using the same methodology (16 different subtypes in 35 samples). The results may not be compared with other reports due to the scarcity of studies related to the subtyping of this agent. AFLP produced a dendrogram (Fig. 2), in which two groups may be observed, with similarity rates equal to $27.5 \%$ and $70 \%$. This finding is similar to the results reported by Maslanka et al. (8), in a study using PFGE. These authors observed that isolates that came from different foodborne outbreaks, although not related, presented similarity rates equal from 40 to $70 \%$.

Based on the results, it may be observed that different SEAFLP patterns were found in isolates of the same animal, which suggests that the technique is highly discriminatory and that the agent presents high variability. The analysis of the dendogram shows that group I was made up of highly heterogeneous samples in relation to biotype, state of origin, animal and herd, and it was not possible to draw a direct epidemiological correlation between them. Isolates of different origin and different biotypes presenting identical SE-AFLP profiles were observed, what suggests a clonal relationship between the strains. This finding may be related to the large distribution of genetic material throughout the country, what leads to the dissemination of different genotypes by the animals that carry the agent.

Samples studied in this trial were obtained from cases of diarrhea and from a small number of animals, what may have influenced the small correlation between the isolates gathered in group I. Although other agents that cause diarrhea have been excluded as a cause of infection in the animals studied, 


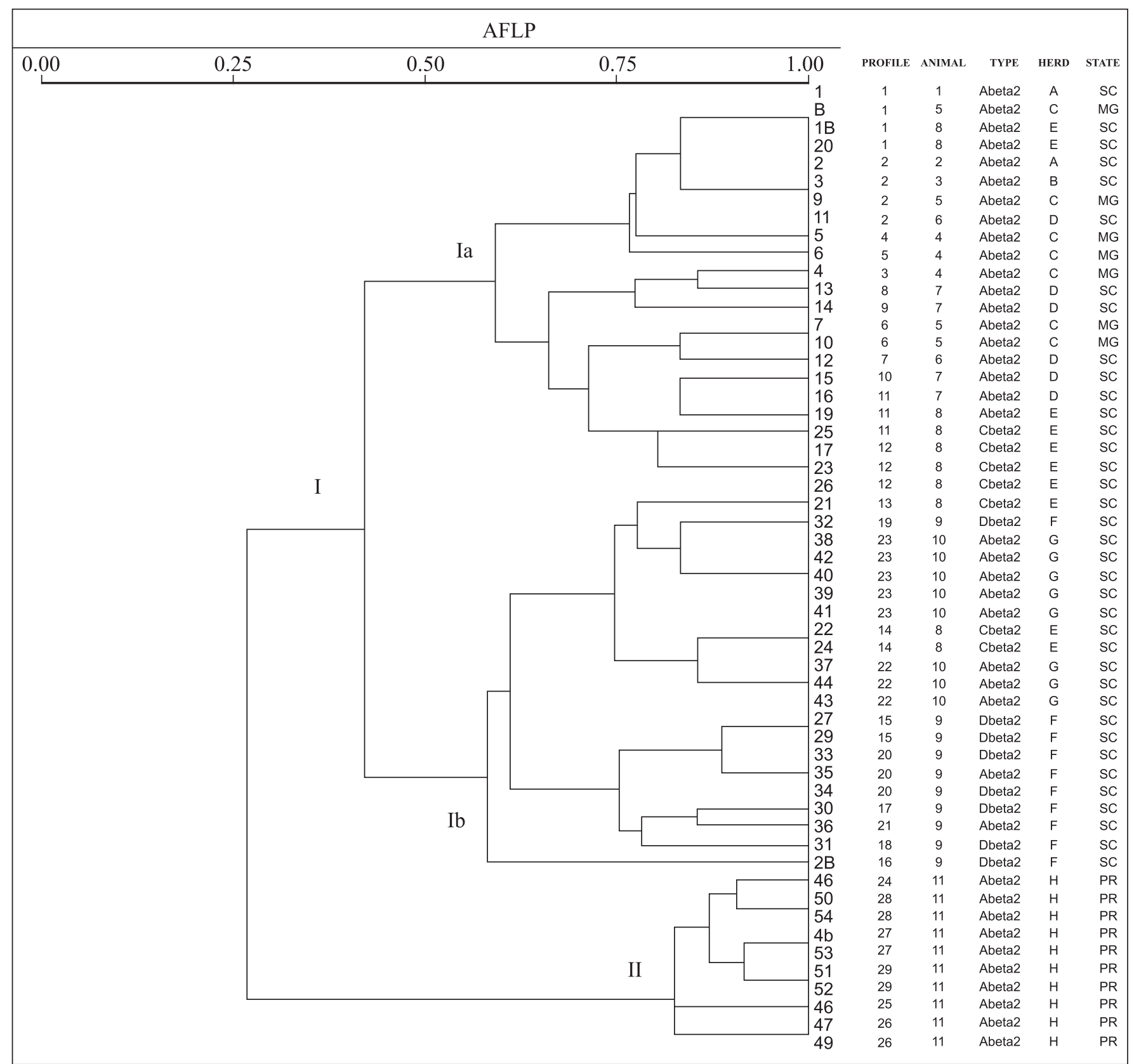

Figure 2. Dendrogram showing the relationship between $C$. perfringens isolates on the basis of SE-AFLP pattern. Percentages of similarity between patterns were calculated by use of Jaccard coefficient. Dendrogram was constructed by use of UPGMA.

there is a possibility that some of the samples studied may belong to normal piglet microbiota, and that they are not related to diarrhea outbreaks. Therefore, an even greater variability may be expected between the isolates, as well as the absence of direct correlation between them. On the other hand, group II presents samples with more than $75 \%$ of similarity, and it was possible to draw a relationship on their biotype and origin.
Nowadays, most of $C$. perfringens genome has been characterized, and it was observed that genes that encode toxins alpha and theta are located on variable regions of the chromosome, near the origin of the replication process, and that genes encoding toxins beta, beta-2, epsilon and iota are located on plasmids that range from 55 to $140 \mathrm{~Kb}(2,6)$. Extrachromosomal location of most of the genes encoding 
toxins may be related to the large diversity of Clostridium perfringens species. It is well known that the presence of mobile genetic elements, such as transposons, insertion sequences, bacteriophages and plasmids may increase the variability of the profiles produced by AFLP and PFGE (3). Loss and acquisition of plasmids and other elements may explain, for example, the presence of different biotypes in the same animal, and samples of different biotypes in the same AFLP profile (2).

All samples tested were typed by SE-AFLP. Maslanka et al. (8) reported that PFGE showed $7 \%$ of $C$. perfringens isolates which could not be subtyped due to the absence of bands, and that the amount of untypable strains in serological tests may reach $70 \%$. SE-AFLP showed to be an easy, quick, low cost technique, with good reproducibility.

No reports were found in the literature related to the description C. perfringens molecular typing in samples isolated from swine. This fact emphasizes the importance of the present study in the evaluation of the SE-AFLP potential in the characterization of $C$. perfringens samples isolated from swine affected by diarrhea.

\section{RESUMO}

\section{Uso do polimorfismo do comprimento de fragmentos amplificados para tipagem de Clostridium perfringens isolados de suínos com diarréia}

Clostridium perfringens é um importante agente infeccioso em medicina veterinária e humana. Em suínos, o agente é responsável pela enterite necrótica e enterotoxemia, caracterizadas por diarréia, perda de peso, atraso no desenvolvimento e morte. No presente estudo foi utilizado o polimorfismo do comprimento de fragmentos amplificados (AFLP), para caracterizar 54 isolados de $C$. perfringens obtidos de suínos com diarréia. A análise dos resultados do AFLP demonstrou 29 perfis distintos com índice discriminatório igual a 0,97 . A correlação entre a origem dos isolados e os agrupamentos obtidos foi parcial, sendo apenas possível a correlação total de $18,5 \%$ das amostras estudadas. A caracterização das cepas em biotipos (A, B, C, D e E), produção da toxina beta-2 e enterotoxina foi realizada através da reação da polimerase em cadeia (PCR). Dentre as cepas analisadas foram observados os biotipos A, C e D, sendo que todas as amostras foram positivas para a presença do gene codificador da toxina beta-2 e negativas para o gene codificador da enterotoxina. Neste estudo, o AFLP demonstrou ser uma metodologia simples, rápida, de baixo custo, com alto poder discriminatório e boa reprodutibilidade, apresentando grande potencial para estudos epidemiológicos envolvendo cepas de $C$. perfringens de origem animal.

Palavras-chave: AFLP, diarréia, suínos, Clostridium erfringens

\section{REFERENCES}

1. Garmory, H.S.; Chanter, N.; French, N.P.; Bueschel, D.; Songer, J.G.; Titball, R.W. Occurrence of Clostridium perfringens beta-2 toxin amongst animals, determined using genotyping and subtyping PCR assays. Epidemiol. Infect., 124(1), 61-67, 2000.

2. Gibert, M.; Jolivet-Renaud, C.J.; Popoff, M.R. Beta-2 toxin, a novel toxin produced by Clostridium perfringens. Gene, 203(1), 65-73, 1997.

3. Gürtler, V.; Mayall, B.C. Genomic approaches to typing, taxonomy and evolution of bacterial isolates. Int. J. Syst. Evol. Microbiol., 51, 3-16, 2001

4. Herholz, C.; Miserez, R.; Nicolet, J.; Frey, J.; Popoff, M.; Gibert, M.; Gerber, H.; Straub, R. Prevalence of beta-2 toxigenic Clostridium perfringens in horses with intestinal disorders. J. Clin. Microbiol., 37(2), 358-361,1999.

5. Hunter, P.R.; Gaston, M.A. Numerical index of the discriminatory ability of typing systems: an application of Simpson's index of diversity. J. Clin. Microbiol., 26(11), 2465-2466, 1988.

6. Katayama, S.; Dupuy, B.; Daube, G.; China, B.; Cole, S.T. Genome mapping of Clostridium perfringens strains with I-CeuI shows many virulence genes to be plasmid-borne. Mol. Gen. Genet., 251(6), 720726, 1996.

7. Klaasen, H.L.; Molkenboer, M.J.; Bakker, J.; Miserez, R.; Hani, H.; Frey, J.; Poppof, M.R.; van den Bosch, J.F. Detection of the beta-2 toxin gene of Clostridium perfringens in diarrhoeic piglets in the Nertherlands and Switzerland. FEMS Immunol. Med. Microbiol., 24(3), 325-332, 1999.

8. Maslanka, S.E.; Keer, J.G.; Williams, G.; Barbaree, J.M.; Carson, L.A.; Miller, J.M.; Swaminathan, B. Molecular subtyping of Clostridium perfringens by Pulsed-Field Gel Electrophoresis To Facilitate Food-Borne-Disease Outbreak Investigations. J. Clin. Microbiol., 37(7), 2209-2214, 1999.

9. Meer, R.R.; Songer, J.G. Multiplex polymerase chain reaction assay for genotyping Clostridium perfringens. Am. J. Vet. Res., 58(7), 702-705, 1997.

10. McLauchlin, J.; Ripabelli, G.; Brett, M.M.; Threlfall, E.J. Amplified fragment length polymorphism (AFLP) analysis of Clostridium perfringens for epidemiological typing. Int. J. Food Microbiol., 56(1), 21-28, 2000.

11. Moreno, A.M.; Baccaro, M.R.; Ferreira, A.J.P.; Hirose, F.H.; Campos, D.S. Detection of the $\beta 2$-toxin gene from Clostridium perfringens isolated in diarrheic piglets. Arq. Inst. Biol., 70, 155-158, 2003.

12. Olive, D.M.; Bean, P. Principles and application of methods for DNA-based typing of microbial organisms. J. Clin. Microbiol., 37(6), 1661-1669, 1999.

13. Pitcher, D.G.; Saunders, N.A.; Owen, R.J. Rapid extraction of bacterial genomic DNA with guanidium thiocyanate. Let. Appl. Microbiol., 8, $151-156,1989$

14. Songer, J.G. Clostridial enteric diseases of domestic animals. Clin Microbiol. Rev., 9, 216-234, 1996. 